Acta Poloniae Historica

118, 2018

PL ISSN 0001-6829

\title{
Anna Machcewicz
}

Institute of Political Studies, Polish Academy of Sciences

\section{POLITICAL PRISONERS IN POLAND, 1944-56: THE SOURCES AND STRATEGIES OF RESISTANCE IN THE AUTHORITARIAN STATE'S PRISON SYSTEM*}

\begin{abstract}
This article seeks to reconstruct the resistance attitudes and strategies of survival among political prisoners in Poland in the years 1944-56, referred to as the Stalinist period. The introductory section reviews the literature on social resistance in authoritarian political systems, including Poland and covering political prisoners. Subsequently, a definition of 'political prisoner' is proposed and the socio-political context of the Stalinist period presented, in which prisons were assigned a strictly repressive function. The present analysis primarily seeks to answer the question whether the conditions in Stalinist prisons offered any room for opportunity to resist the authoritarian power - and, if yes, what sort of experiences and models the convicted resorted to. I also sought to see what forms rebellion against the authority assumed and what was the purpose of the adopted survival strategies. The article is based on documents generated by the Ministry of Public Security's Prison Management Department and the penitentiary units reporting to it, as well as on memoirs and accounts of former political prisoners.
\end{abstract}

Keywords: political prisoner, social resistance, social capital, Stalinism, authoritarianism, post-war communist Poland (People's Republic of Poland/'People's Poland')

\section{I \\ INTRODUCTION}

In the autumn of 1956, the Warsaw attorney-at-law Józef Stopnicki hosted a group of few attorneys and members of the Polish Socialist Party (Polska Partia Socjalistyczna - PPS) and former Stalinist prisoners. The attendees were to consider whether to pursue efforts towards legal

* This text has been completed as part of the research project no. 2016/23/D/ HS3/00426, funded by the National Science Centre (NCN) in Poland. 
rehabilitation of the organisation's members sentenced in the years 1946-8 for attempts to forcibly overthrow the regime of the State of Poland. Ludwik Cohn, who was at the meeting, stated that political trials were a means of political struggle and authoritarian systems used them as a means of destroying the political opposition. After the old regime collapsed, he said, former prisoners can speak up again, and use the authority they have built up among their followers with the long years of their fighting and persecutions; some join the new State authorities. Their guilt has merely disappeared. Rehabilitation by giving the floor to those who were persecuted until very recently, he argued, is what makes real sense. This would namely mean that freedom of speech and political struggle has prevailed. Hence, the idea of considering by courts of law the 'political sins' of former prisoners can only mean that no real political change has been brought about. The attendees finally came to the conclusion that they would quit pursuing rehabilitation. ${ }^{1}$

The rehabilitation privilege was however sought by some Home Army (Armia Krajowa - AK) members who had been sentenced for their alleged collaboration with the German Nazi occupiers and now wanted to be cleansed of the stigma of treason, and by those groundlessly accused of espionage. However, rehabilitation was a tough choice for a number of former political prisoners, of whom many had spent years behind the bars for their actual participation in the post-war conspiracies. First, the story told above makes us aware how complex a notion the political prisoner status was in the Stalinist years as well as in the Thaw following the ground-breaking October 1956 events. Second, one faces the question how come a political prisoner has preserved the ability to think independently and the will to resist, given the many years of serving time in a harsh prison where the regime endeavoured to deprive its victims any hope whatsoever.

The problem of resistance and survival strategy of individuals in face of the authoritarian regime, and, of organising a life and forms of subordination or contestation, has been addressed by a number of authors. Lynne Viola argued that resistance formed an autonomous world that functioned along the power and interacted with it, evolving in time. Orlando Figes demonstrated how the private world and the official world coexisted in practice, forming the social tissue of

${ }^{1}$ Aniela Steinsbergowa, Widziane z tawy obrończej (Warszawa, 2016), 198-202. 
the Soviet Union. Resistance and opposition in the USSR and East Central Europe (East Germany, Czechoslovakia, Romania) have been addressed by several scholars, including Klára Pinerová, Bettina Greiner, and Romulus Rusan. ${ }^{2}$ In his recent book, Padraic Kenney, referring mainly to Polish, Irish, and South African experiences, traces the role and forms of action practiced by political prisoners as part of a broader combat pursued by the political opposition and struggle for human rights. ${ }^{3}$

The attitudes of resistance and opposition towards the power system in communist Poland have been addressed by Polish researchers such as Dariusz Jarosz, Andrzej Paczkowski, Andrzej Friszke, Hanna Świda-Ziemba, and Łukasz Kamiński. ${ }^{4}$ Polish historiography has so far yielded a few monographs of Stalinist prisons, describing the living and working conditions of the inmates and repressive measures applied against the political prisoners in the years $1944-56 .{ }^{5}$ A monograph dealing entirely with everyday living and labour conditions in prisons of Stalinist Poland has been penned by Tadeusz Wolsza. ${ }^{6}$ An important

${ }^{2}$ Orlando Figes, The Whisperers: Private Life in Stalin's Russia (London, 2007); Bettina Greiner, Suppressed Terror. History and Perception of Soviet Special Camps in Germany (Lanham, 2014); Klára Pinerová, Everyday Life of Prisoners and the Preservation of Their Moral Integrity in the Czechoslovak and East German Prisons after the Second World War in Marja Wakounig (ed.), From Collective Memories to Intercultural Exchanges (Münster, 2012), 210-25; Romulus Rusan, The Chronology and the Geography of the Repression in Communist Romania: Census of the Concentration Camp Population 1945-1989 (București, 2007); Lynne Viola (ed.), Contending with Stalinism: Soviet Power and Popular Resistance in the 1930s (Ithaca, 2002).

${ }^{3}$ Padraic Kenney, Dance in Chains. Political Imprisonment in the Modern World (Oxford, 2018).

${ }^{4}$ Andrzej Friszke, Między wojna a więzieniem 1945-1953. Mtoda inteligencja katolicka (Warszawa, 2015); Dariusz Jarosz, Polacy a stalinizm 1948-1956 (Warszawa, 2000); Łukasz Kamiński, Andrzej Małkiewicz, and Krzysztof Ruchniewicz, Opór społeczny w Europie Środkowej w latach 1948-1953 na przykładzie Polski, NRD i Czechostowacji (Wrocław, 2004); Andrzej Paczkowski, 'Polacy pod obcą i własną przemocą', in Stéphane Courtois et al., The Black Book of Communism: Crimes, Terror, Repression (Cambringe MA, 1999); Hanna Świda-Ziemba, Cztowiek wewnętrznie zniewolony (Warszawa, 1997).

${ }^{5}$ Krzysztof Czermański, Więzienie w Sztumie w epoce totalitaryzmów 1933-56 (Pelplin, 2014); Jerzy Czołgoszewski, Więziennictwo okresu stalinowskiego na Warmii i Mazurach w latach 1945-1956 (Olsztyn, 2001); Mirosław Pietrzyk, Więzienie w Inowrocławiu w latach 1945-56 (Gdańsk, 2004); Marcin Zwolski, Więzienie w Biatymstoku w latach 1944-56 (Białystok, 2011).

${ }^{6}$ Tadeusz Wolsza, Więzienia stalinowskie w Polsce. System, codzienność, represje (Warszawa, 2013). 
study addressing the attitudes of Stalinist women prisoners as a discernible group has come Anna Müller, a Polish-American scholar. ${ }^{7}$ A detailed reconstruction of investigations against communist activists as part of faction fighting within the ruling party (Polish United Workers' Party [PZPR]) under Stalinism in its climax in Poland, with threads of individual resistance attitudes, has been proposed by Robert Spałek. ${ }^{8}$

Most of those Polish studies address the questions of organisation of the prison life and the repressive function of Stalinist system of prison organisation and management; resistance offered by individuals to the authorities has not been studied in detail yet. This article addresses the issue of strategies of political prisoners' resistance under the authoritarian regime of communist Poland in 1944 to 1956 . According to a classical definition of totalitarianism (Friedrich, Brzeziński, Arendt ${ }^{9}$ ), its imminent characteristics include an all-embracing and expansive ideology supported by force of terror, and the strife to force the dominant ideology's principles into the minds of all the citizens, so that they become its militants and campaigners - not out of coercion but by way of voluntary commitment. Most of the researchers say that such features were indisputably characteristic of what was termed 'People's Poland' in the period $1949-53 .{ }^{10}$ The post-war years, especially 1944/5-7, marked an interim period, which extended to the prison system. Supervision of prisons was immediately passed on to the Ministry of Public Security (Ministerstwo Bezpieczeństwa Publicznego - MBP), but some prison officers governors came from the pre-war staff or were not necessarily committed to the new authorities. Because of this, they were watched carefully and evaluated in respect of loyalty; some were dismissed, if found not loyal enough. In 1954, with the escape of Józef Światło to the West and his exposure of the

${ }^{7}$ Anna Müller, If the Walls Could Speak. Inside a Women's Prison in Communist Poland (Oxford, 2018).

${ }^{8}$ Robert Spałek, Komuniści przeciwko komunistom. Poszukiwanie wroga wewnętrznego $w$ kierownictwie partii komunistycznej $w$ Polsce $w$ latach 1948-1956 (Poznań, 2014)

${ }^{9}$ See Hannah Arendt, The Origins of Totalitarianism (New York, 1951); Carl J. Friedrich and Zbigniew Brzeziński, Totalitarian Dictatorship and Autocracy (Cambridge, 1967).

${ }^{10}$ See Paweł Machcewicz, 'Zmiana czy kontynuacja? Polska przed i po Październiku '56', in Dariusz Stola and Marcin Zaremba (eds.), PRL. Trwanie i zmiana (Warszawa, 2003), 119-59. 
abuses practiced by the Ministry, the political erosion wave helped considerably improve the conditions of serving prison sentences also for political prisoners. The oversight of prisons was moved to the Ministry of Home Affairs (Ministerstwo Spraw Wewnętrznych - MSW), the role of public security officers was reduced and ideological pressure relaxed. It can be agreed that the period when prisons in Poland were completely subjected to supervision of the authorities was confined to the years $1948-53$.

As Michel Foucault remarks, resistance is possible whenever the person has a minimum space for practicing his or her freedom, ${ }^{11}$ even within prison settings. The question is worth posing, though, what were the 'mobilisation resources' that helped the regime's victims survive and preserve the integrity of their views and ideas. ${ }^{12}$ In his theory of social change, Piotr Sztompka uses the notion of social capital, and remarks that life opportunities of individuals and collectives are conditional upon the unique balance of positive and negative relationships, particularly moral and amoral ones: a balance that is rooted in a more and less remote future. He claims that society is subject to change under the influence of features of individual persons and within the structures inside which they operate. Both factors are "derivable from the character of their private relationship networks and collective networks of relationships in the groups they belong to; and thereby, from the shape of individual and collective or group interpersonal spaces ... I am what those I have ever come across have made me" ${ }^{13}$ Polish political prisoners of the Stalinist period were

${ }^{11}$ See Paul Rabinow (ed.), Ethics, Subjectivity and Truth, Essential works of Foucault 1954-1984 (New York, 1997).

${ }^{12}$ I refer at this point to the resource mobilisation theory, developed by Charles Tilly and others, and to social interactions (being Tilly's key notion). Tilly explains the incentives behind the actions performed by the actors founded by conscience factors, the role of cultural patterns, the context, and previous experiences. The researcher ought to identify regularities appearing in social behaviours of people responding to the situations they come across and proactively influencing the social environment. What we deal with in concrete 'social situations' is a two-way action of structures and individuals. Hence, substantial about the research should be to trace the results of action under historically determined confinements. See Agnieszka Kolasa-Nowak, Socjolog w badaniu przesztości. Koncepcja socjologii historycznej Charlesa Tilly'ego (Lublin, 2001).

13 Piotr Sztompka, Kapitat spoteczny. Teoria przestrzeni międzyludzkiej (Kraków, 2016), 257. 
gradually subjected to a hardly bearable isolation, brutal oppression, and permanent ideological pressure. In practicing resistance, they could make use of the resources elaborated by the longstanding tradition of struggle for the sovereignty of the state and one's own beliefs and conditions. The massive and widespread nature of Stalinist repression, particularly in the years 1949-53, caused that many of the condemned were individuals of a strong ideological and political identity whereas, on the other hand, people were put in prison by mere chance, their views indeterminate. Were they becoming a malleable material for the authorities' propaganda purposes? Could a struggle for the 'rule of hearts and minds' be taking place between the oppressive regime and its ideological opponents in the prison conditions?

II

\section{WHAT IS A POLITICAL PRISONER?}

Political prisons are erected when regime wishes to demonstrate their strength to those opposing it. The opponents are thus isolated, their actions and words stigmatised; they are sentenced to long years in prison, in bad conditions, not infrequently with torture used against them. Those in power aim at forcing the victims to end their oppositional activities and stay silent, or even to doom them to oblivion, while those remaining at large are given the warning message to cease objecting. Since the late nineteenth century, oppositionists elaborated and mastered a system of defence against such oppression over the subsequent decades and under different regimes. ${ }^{14}$

Related to this issue is the more general regularity which is connected with the building of communities inside and outside prison, opportunities of combat for the prisoner's rights and offering resistance. The prisoner, not necessarily political and regardless of the system in which they serve their sentence, follows certain unchanging principles that function in the enclosed environment of convicts. Since they become deprived of their fundamental rights, they create their own laws and institutions. ${ }^{15}$ These actions are meant to help preserve the individual's subjectivity or empowerment, and self-respect, be it at the expense of additional repression. For a political prisoner,

14 See Kenney, Dance in Chains.

${ }^{15}$ See Marek Kosewski, Ludzie w sytuacjach upokorzenia i pokusy (Warszawa, 1985). 
the prison area becomes a new battlefield, the final and conclusive goal of his/her battle being freeing himself/herself, revolution, and participation in power. ${ }^{16}$

Political prisoner refers one to a status that is deeply rooted in the Polish tradition which emerged in the last decades of the nineteenth century. The people fighting for their convictions and beliefs created models of self-defence and conduct when under investigation. In specific, the interrogated basically ought to deny any membership or affiliation with their organisation and see to that the record is signed in a way so as to prevent adding even a single word. Kazimierz Pużak, member of the Polish Socialist Party, one of the leaders of the Polish Secret State during the Second World War, a consummate conspirer, trained to this end in a tsarist prison (in the partitioned Poland), followed the old socialist rule: while interrogated, he never knew about anything and never owned anything up. ${ }^{17}$ During the German Nazi occupation of Poland, in 1942, special instructions for prisoners were compiled by the Secret State, where it was clearly stated that restraint and reserve while testifying offers maximum safety and efficiency. The major rule said, never trust your fellow-prisoners, even if you know them well or they are close to you, for they might have broken down in the investigation; under no pretence should the imprisoned person enter into agreement with the Gestapo in exchange for release or collaboration. ${ }^{18}$

The sentenced were bound by the specific rules of inmate coexistence and methods of defending the political prisoners' rights by their unincarcerated comrades. The rules had been worked out for decades, especially in the Russian Partition before 1914; the tradition was followed up in interwar Poland, particularly in the communist milieu. Political prisoners did enjoy certain privileges: they could use their own clothes and bedclothes, exchange letters more often than the criminal inmates, talk freely to inmates from other cells when in the prison yard, and to read legal newspapers, brochures or books available from the prison library. They could lecture and facilitate political discussions. In fact, prison communes were formed

${ }^{16}$ Kenney, Dance in Chains, 162.

${ }_{17}$ Roman Kruszewski and Wanda Tycner, Proces Kazimierza Pużaka (Warszawa, 1992), 19.

${ }^{18}$ Kenney, Dance in Chains, 70-1. 
of all the political prisoners confined in the prison, with a secret self-government and their own set of rules. In line with the unwritten law, they demanded that their right to education or to be released from labour be respected. After 1926, Polish authorities tried to gradually restrict these privileges; the prison rules adopted in 1932 had the category of political prisoner deleted. Yet, the prisoners' self-awareness did not disappear: they organised protests and riots within prisons, and enjoyed support from their fellows at large as well as from the press and international organisations. ${ }^{19}$ Making the fact of their detention and possible repressions public contributed to building the special position of the imprisoned as martyrs and leaders of their movement whilst also providing a guarantee of their security and of respect for their rights behind the bars.

\section{III}

\section{POLISH POLITICAL AND SOCIAL CONTEXT IN 1944-56}

In the Soviet Union under Stalinist rule, the political battlefield was reduced to zero. The system developed by Joseph Stalin endeavoured to gradually encroach all the areas of human life: the power was centralised and the economy taken over by the state, whereas a new ideology was developed and culture and arts squeezed into the frame of socialist realism; persecution and human suffering became prevalent. Repressions stroke blows at the social groups, one by one, disintegrating them and forcing people to act in new circumstances. This made them, at times, cut themselves off from their past, disowning those close to them, relatives or friends. Apart from coercion, there was the other side of the coin: Stalinism was accepted by millions, who saw it as a necessity ensuing from the prevalent political situation in which one had somehow to live.

This model of power appeared in Poland with the arrival of the Red Army and the installation of the Polish Committee of National Liberation [PKWN]. It expanded step by step over a few years, clearly becoming a copy of the Soviet system since the late 1940s - as was the case with all the East Central European countries. After Stalin's

19 See, inter alia, Stefania Sempołowska, W więzieniach (Warszawa, 1960); Krzysztof Urbański, 'Sytuacja komunistów w więzieniach województwa kieleckiego w latach 1918-1939', Rocznik Muzeum Narodowego w Kielcach (1980), 39-55. 
death, a political thaw arrived - initially in the Soviet Union and subsequently extending to the other communist countries. With the nomination of Władysław Gomułka as First Secretary of the communist party (PZPR) in October 1956, Stalinism in Poland finally came to an end. Ever since, the past years were referred to as a 'period of errors and distortions'; political trials were no secret any more.

This context is important if one wants to understand the society's attitude towards the new authorities. The country after the war was very poor, devastated by the war, and, in fact, backward in a number of respects, compared to Western Europe. The modernisation slogans, such as industrialisation, agricultural reform, universal education, or care for health, were part of the programs of most Polish political parties when the war was still on. Schools, including higher schools, were being rebuilt; combating illiteracy was approached as a very serious affair. In its communist version, industrialisation assumed a pretty radical form; yet, nobody would challenge the need to pursue it. People from small towns or villages attracted by towns might have had a feeling that it was right there, in the shipyard or factory, and around it, that the real life went on. This promise of a better life was multiplied by the omnipresent propaganda that worked through cinema, posters, or architecture. The group of ideology-imbued devotees was not enormous in the Stalinist years, but otherwise the people could not quit their jobs, turn their backs on the reality, or emigrate en masse. Even if they criticised the system, they would keep such opinions for themselves or share them with those closest to them, fearing being controlled by the public security apparatus and denunciation that burgeoned in the favourable circumstances of escalating terror.

Yet, there were such who rebelled. Rebellion, or resistance, took more or less radical forms. The disagreement was expressed through various forms of conspiracy rooted in the Home Army [AK] or National Armed Forces [NSZ] practice and surviving after the war. The conspirers were put in prisons, especially in the first post-war years, and filled up prison cells with long prison sentences. Clandestine organisations were set up also by young people, of junior-high or secondary school age, who followed the occupation-time models of their elder brothers or parents. Imprisonment sentences were moreover passed on pre-war politicians who remained at the margins of public life. On 4 June 1947, the Ministry of Public Security passed a search warrant for the 
apartment of Kazimierz Pużak, the doyen of Polish socialists, and arrested the man. With the strengthening Stalinism, the society was increasingly managed by fear. Terror was targeted at various social groups: the Polish Army officers with pre-war curriculum vitae, former soldiers of the AK and the Polish Armed Forces in Western Europe. It also affected those circles which found some field for action for themselves within the system they had never accepted. A group of landowners, experts in agrotechnology, employed at the headquarters of State-owned Real Landed Properties were detained in 1949: they were accused of acting to the detriment of the State, sabotage, and even espionage, and were all given life imprisonment sentences. ${ }^{20}$

In 1949, at a meeting of the Secretariat of the Central Committee of the PZPR, Hilary Minc, First Deputy of the Chairman of the Council of Ministers and the state's chief economist, demanded that "indiscriminate attack" should be launched at the Church. Priests were accused on "favouring the gangs", "practicing whispered propaganda", and violating the conscience protection decree. ${ }^{21}$ Early in the 1950s, the Jehovah's Witnesses were collectively regarded as political opponents, and their mass arrests began. ${ }^{22}$ One could be put in prison at that time with a severe political charge such as espionage or sabotage, even if the accused was not really an opponent of the system. Arrest waves affected people with no markedly crystallised political views. Men and women whose acts were nowise commensurable with their verdicts were kept in prisons for years. In March 1950, a certain Jan Hain, a worker at the power generator factory in Gliwice, Silesia, was detained. "The accused has twice inserted pieces of metal the between the coils ... in the generators; as a result, when started up, these coils would have been damaged, which would in turn have caused the need to wind the coils, thus causing losses in the electricity output", the Military District Court in Katowice pronounced, sentencing the defendant to eight years in prison for sabotage. ${ }^{23}$ Rigged espionage

20 Tomasz Osiński, “"Klika obszarnicza”. Ziemianie w polityce personalnej Państwowych Nieruchomości Ziemskich (1946-1949)', Pamięć $i$ Sprawiedliwość, $\mathrm{xx}, 2$ (2012).

${ }^{21}$ Jan Żaryn, Dzieje kościoła katolickiego Polsce 1944-89 (Warszawa, 2003), 126.

22 Anna Chabasińska. 'Polityka władz wobec mniejszości wyznaniowych w Polsce w latach 1945-1956', Studia Lubuskie, v (2009), 37-62.

${ }^{23}$ Instytut Pamięci Narodowej (Institute of National Remembrance, IPN), Ka 08/102, Investigation file - the case of J. Hain, 57. 
trials have victimised a group of labourers, repatriates from France, who were accused of membership of the French intelligence and setting fire on a factory in Elblagg, since they had sporadically stayed in touch with the French Consulate. ${ }^{24}$ Those whose alleged membership with an illegal organisation or assisting behaviour was not proved to the satisfaction of the court were basically liable under Paragraph 18 of the Decree of 13 June 1946 'on crimes particularly dangerous during the reconstruction of the State', which provided for punishing for "not having informed of a crime or offence": the clause was colloquially referred to as 'knew well, didn't tell'. ${ }^{25}$

The prisoner community of opponents of the political regime included, moreover, a group of Ukrainians, whether sentenced for their Ukrainian Insurgent Army [UPA] membership or civilians accused of supporting this organisation (some of them being Greek Catholic priests). Lastly, communists gaoled resulting from the incremental spy-mania and internal power struggles formed yet another group of political prisoners.

IV

POLITICAL PRISONERS AND THE STALINIST

'PENITENTIARY POLICY'

Although they have become emblematic for the Stalinist period, political prisoners never accounted for a majority of the convicts; and yet the proportion of those sentenced for what was termed 'anti-State activities' was always significant. This particular prisoner category, extensive and imprecise as it was, was repeatedly altered in the prison regulations and reports. According to the penitentiary statistics, the 'anti-State' prisoners accounted for some 35 per cent of all the convicts in late 1946. The category officially included those accused of collaboration with the German occupiers; it is impossible to determine, even if approximately, to what degree such collaboration or cooperation might have been actual or whether the charge was hasty, or has resulted from entangling innocent people by the secret

${ }^{24}$ Maria Pasztor and Dariusz Jarosz, Robineau, Bassaler i inni. Z dziejów stosunków polsko-francuskich w latach 1948-1953 (Toruń, 2001), 210-11.

${ }^{25}$ For a systematic review of the Polish criminal law regulations in 1944-56, see Zdzisław A. Ziemba, Prawo przeciwko społeczeństwu (Warszawa, 1997). 
police. Following the amnesty of 1947 and the subsequent wave of arrests in mid-1948, at least 20 per cent of political prisoners were kept in prisons. ${ }^{26}$ An evident increase in this proportion appeared in the early fifties, probably due to the intensified activities of youth conspiratorial organisations, on the one hand, and intensified terror and surveillance, on the other. Even the pettiest delinquency could have put a man in prison. According to the MBP's Prison Management Department, in 1950, more than 66,000 people were kept in prisons and prisoner labour centres all over the country (excluding detention facilities and custody suites), after the German civilians and POWs were released from the camps; approximately 29,000 out of this figure were sentenced for common offences or crimes. ${ }^{27}$

In official terms, prisoners were categorised into 'prisoners on remand' and 'sentenced prisoners' throughout the period in question. A categorisation with respect to the character of crime/offence was first introduced in autumn 1944, the prisoners having been classed into 'anti-State', 'criminal', and 'Volksdeutsch'. A few months later the 'anti-State' ones were divided into 'accused of espionage' and 'Home Army, National Armed Forces, and the like'. The category of 'Volksdeutsch' disappeared in 1951. In the earliest post-war years, the nationality/ethnicity of the prisoners was remarked in the statistics received from the prisons; this particular category was in force till the late forties.

In as early as autumn 1944, Teodor Duda, the then-head of the penitentiary system, issued a circular specifying the regulations regarding the deployment of prisoners: "I strictly forbid that prisoners accused of anti-State activities be incarcerated together with those of any other category, whatsoever. The so-called 'Volksdeutsch' prisoners and those accused of collaboration with the Germans shall not be incarcerated together with any prisoner accused of anti-State activities, whosoever" ${ }^{28}$

The segregation was meant to be mainstreamed by the appointment, in 1948, of a few facilities to which almost exclusively 'anti-State' prisoners were dispatched. Women were directed to Fordon (the central

${ }^{26}$ Marcin Zwolski, Więzienie w Biatymstoku w latach 1944-1956 (Białystok, 2011), 213.

${ }^{27}$ Archiwum Akt Nowych (State Archives of Modern Records, hereinafter: AAN), MBP DW, sygn. 17/12; a statistical report, 1-2.

${ }^{28}$ Zwolski, Więzienie w Biatymstoku, 214. 
prison for female inmates, situated outside Bydgoszcz) whereas men were incarcerated in Rawicz and Wronki. In 1952, an isolation ward for women functioned within the Inowrocław prison; men's sections existed in Sztum, Barczewo, and Goleniów. ${ }^{29}$

In practice, however, 'anti-State' prisoners with lighter sentences were distributed among the other penitentiary facilities all over the country. The circulars and instructions from the headquarters regarding the segregation tended to be rather unrestrainedly interpreted in those prisons. A week's stay of an inspector representing the Prison Management Department's Political and Educational Section at the criminal prison in Sieradz in 1948 yielded a report pointing out to the administration that several prisoners of varied ages, criminal records, social background, and degrees of penalty were placed in one cell. "Only the prisoners sentenced for their membership with the UPA and the NSZ have been placed in separate cells", the inspector noted. ${ }^{30}$ The report suggested that recidivists and those convicted "for the UPA and the NSZ", for collaboration with the Germans, women, and ailing prisoners be relocated to other prisons. Interestingly, this particular document does not mention the categories of 'anti-State' and 'criminal' at all.

The afore-quoted report could have heralded an impending change. The cells in the Sieradz prison were to be inhabited ever since by healthy men only, who would thus become a source of cheap labour force for the local workshops and other workplaces. Another point of the 'penitentiary policy' proposed by the report's author was to launch "large-scale cultural and educational project" that would include a dayroom, two radio-sets with speakers, a chess set and some new books (to be purchased), and subscription of newspapers. The segregation was used for the preparation of an efficient manufacturing plant, with production standards to be met and "labour competition". Toward the end of the 1940s, labour camps for German civilians and POWs, thitherto the main providers of unpaid labour force, were emptied. ${ }^{31}$

${ }^{29}$ AAN MPB DW, sygn. 76: Memo from Ltn. Col. Hipolit Duljasz, Head of the Department, to Gen. Stanisław Radkiewicz, Minister of Public Security, 24.05.1952, 38.

${ }^{30}$ AAN MBP DW, sygn. 375: Report on the inspection at the prison in Sieradz, 12.1948, 65-9.

${ }^{31}$ On the functioning of Polish forced labour camps in the years 1944-50, see Sebastian Rosenbaum and Bogusław Tracz, Obozy Pracy Przymusowej Gliwickiego Zjednoczenia Przemystu Weglowego 1945-1949 (Katowice, 2009); Kazimierz 
In lieu of the former inmates, the state authorities decided to employ all the convicts who were fit for work. Some would be hired by the prison production plants and agricultural colonies, the others being allocated to the so-called Prisoner Labour Centres whose staff was hired by the nearby factories, mines, or quarries.

The principle that political opponents needed being isolated, since they were unanimously perceived as unworkable 'enemies', was losing in importance in favour of the economic argument. This, in turn, called for new segregation rules. The instructions whereby prisoners were classed into three categories entered into force in 1950. The group marked 'A' denoted prisoners found the most dangerous to the social order, hardened enemies of the 'People's' Poland', who have committed crimes due to their social background; such individuals were "oriented or remained bound for life or death with the exploiting classes", and their sentences were above eight years (further to the amnesty of 1952, their number was estimated as less than 6,000). Group 'B' included less dangerous 'enemies of state', who have served as "instruments used by the enemy centres due to their poor political sophistication and low intellectual level". The group marked 'C' was devised for prisoners whose activities have resulted, according to the said instructions, from "their corruption by the conditions of the war, the occupation, and the capitalist habits, a very low degree of political and social awareness, and, political disorientation". ${ }^{32}$ Albeit the principle of isolating those whom the authorities considered the most dangerous opponents of the system was maintained, the regulations in force gave the penitentiary administration considerable interpretive freedom. It was the assessment of the prison warden and the officer of the special section (reporting directly to the Prison Management Department) that decided whether the prisoner was still dangerous and thus could work or not.

Resulting from the 1952 amnesty, over 30,000 prisoners were set free, and the Prison Management Department resolved to qualify 1,500 'A'-classed persons for labour. Moreover, Ltn. Col. Duljasz, Head of the Department, resolved to employ all the 'A'-category prisoners, "at

Mieroszewski, Obozy pracy przymusowej na terenie Katowickiego i Chorzowskiego Zjednoczenia Przemystu Weglowego 1945-1950 (Katowice, 2002); Andrzej Topol (ed.), Obozy pracy przymusowej na Górnym Ślasku (Katowice, 1994).

32 AAN MBP DW, sygn. 1122: List of prisoners to continuously serve the sentence of imprisonment after the possible application of the Amnesty Bill, 5 July 1952, 43. 
the last stage of serving the sentence", in production establishments within the prison premises. ${ }^{33}$

With the new regulations on segregation, the Prison Management Department determined the principles of a specifically understood policy of gradual alleviation of the prison regime with respect to prisoners, including 'anti-State' prisoners. The regulations and the penitentiary practice in interwar Poland were meant to establish a progressive system whereby the main function of the prison was to enable social rehabilitation. The system was designed so as to divide the custodial sentence into several stages, the imprisonment conditions being alleviated as the convict was getting corrected. ${ }^{34}$

The rules prepared by the Ministry of Public Security emphasised the ideological aspects; a prisoner could be re-classed from 'A' to 'B' as "metamorphosis progressed in the prisoner". ${ }^{35}$ Those who demonstrated a radically inimical attitude, "continuously oriented toward combat against the people's rule", were incarcerated in separated sections, isolated, and subjected to a severe regime. In the Wronki prison and in the isolation wards at Rawicz, Fordon, or Inowrocław, such inmates were denied the right to any employment whatsoever, and were barred access to books and newspapers. The administration had a whole repertory of severe punishments, starting with solitary confinement, ban on walking in the yard, temporary confinement in a worse (for instance, poorly illuminated) cell, and ending with ban on seeing visitors, write letters, or buy items from the prison canteen (based on the canteen fund [Polish: wypiska]). ${ }^{36}$ Isolation and use of deterrent punishments even for the slightest offence was meant to break the prisoners down; those inmates who "have quit fighting and have assumed a passive attitude" could be reclassified by the personnel to group 'B'.

${ }^{33}$ AAN MBP DW, sygn. 76: Memo from Ltn. Col. Hipolit Duljasz, Head of the Department, to Gen. Stanisław Radkiewicz, Minister of Public Security, 24.05.1952, 78.

${ }^{34}$ Krzysztof Chmielewski, 'Polska doktryna prawa penitencjarnego w okresie międzywojennym', Czasopismo Prawno-Historyczne, lxviii, 1 (2016), 179-200.

${ }^{35}$ AAN MBP DW, sygn. 76: Memo from Ltn. Col. Hipolit Duljasz, Head of the Department, to Gen. Stanisław Radkiewicz, Minister of Public Security, 24.05.1952, 79.

36 Tadeusz Wolsza, W cieniu Wronek, Jaworzna, Piechcina... 1945-1956 (Warszawa, 2003), 58-64. 
The instructions that dealt with methods of influencing the prisoners provided for an array of measures. 'Solidarism' was to be eradicated in order to fuel mutual distrust within the cell, which was inspired by the agents inhabiting it. Prisoners were to be indoctrinated by means of chats, reading newspapers together, reading assignments and films selected for the purpose. Also, impacts were exerted on the inmates' psyche by coupling long-term, 'broken down' prisoners with those who manifested a 'positive' attitude toward the political regime. Those who in the opinion of the prison's staff showed signs of 'breakdown' were allowed to use the press and literature, primarily Marxist, and were sent to work ${ }^{37}$; they could be given an order-keeping function or be employed at a workshop within the prison area. As a reward, some were allowed to meet their families in better conditions, without the separating net.

As is thus apparent, the authorities sought to have almost completely isolated those prisoners who were perceived as the 'opinion leaders' and who could enhance the morale of their fellow inmates, and to smash the inmate community. While the use of prisoners for economic purposes became a clear incentive at some point, the political purpose consisting in complete isolation and indoctrination was pursued systematically and consistently.

There was one more important aspect as far as the living conditions of Stalinist political prisoners are concerned. As has been mentioned before, the point of reference provided by the opposition movement at large is prevalently important: while building the imprisoned individuals' hope, it simultaneously added to the unique authority of the companions suffering behind the bars. In the post-war communist Poland, external observers, social or international organisations, or mass media had any possibility to act gradually reduced down to nearly nought. The prisoners could feel forgotten, atomised, their cause lost. They received no news from the world at large, and no message from them would reach outside the bars. So, could those people, who were meant to be broken down, with a number of measures employed to this end and with no organisational support from the outside, still add any meaning to their fate? What were the behaviours, models, and values they resorted to?

${ }^{37}$ AAN MBP DW, sygn. 76: Report of Deputy Head of the Political and Educational Section, Prison Management Department, Ministry of Public Security, 14 May 1952, 67. 
THE BACKGROUND OF POLITICAL PRISONERS' RESISTANCE: CULTURAL MODELS AND RESOURCES

I should like to start my argument by remarking that the present article only deals with the community of the 'anti-State' prisoners. People sentenced for political offences and placed in a prison environment dominated by real criminals had to wrestle with specific problems. Cut off from their natural environment, they fought for survival in an alien world governed by its own laws. Janusz Horodniczy, who at the moment of his detention was seventeen of age, high-school student, and was sentenced for his involvement in youth conspiracy, recalled that, surrounded by young criminals for several weeks, he consented to have his whole body tattooed. ${ }^{38}$ Teresa Lechowska, sentenced to two years in prison as a student, was gaoled at the Gęsiówka prison in Warsaw, in a cell populated by forty women - local thieves, prostitutes, shop assistants caught on deficit-making. She was appointed cell supervisor there, and the cell-mates probably expected her to inform on people. This would expose her to chicaneries from them, so at once she said to them she knew what she was appointed for, and she intended to inform on nobody. At the same time she asked the women to act fairly decently here, not to expose her, because they have come here for a few months while she has got two and a half years. "And they were very loyal towards me indeed, no rebelling, or anything of the sort whatsoever". The female prisoner's position was built not quite by her politically determined sentence but owing to her education. Her cell mates requested her to write applications for early release. She managed to build basically good relationships with them as she avoided evaluating their social status: "who am I, after all, to judge a prostitute?"39

Once sentenced, Wanda Olszewska was placed in a prison for juvenile women in Bojanowo, where a small group of female political and criminal prisoners were put together into multi-person cells. One of them got three years for killing her baby' "My sentence was twelve years. I probably wouldn't be thinking this way to-day, but then I had a grudge against the fortune that we'd been put there together, sharing a cell", recollects she; sharing the cells with she-criminals must

38 Janusz Horodniczy, Młodsi od swoich wyroków (Łomianki, 2010), 56-7.

${ }^{39}$ Account of Teresa Lechowska, 2010 (kept in the author's collection). 
have been hardly bearable for her indeed. "We, the 'political', stuck together. We maintained no contact with the 'criminal' but did live amidst them in one cell. They were quarrelling, at loggerheads with one another. There were lesbians too, they'd get into one bed, and I didn't know what it meant". Bojanowo was a low-security prison. With the help of a guard, Olszewska escaped into freedom, together with a companion; however, they were caught a dozen days later. At that point, she was moved to Fordon, where she shared a cell with other (female) political prisoners. Although the living conditions there were much harder compared to those in Bojanowo, she had better recollections from Fordon: She named her fellow prisoners her friends and claimed they all supported each other. "There was Ms. Chmielewska, who shared half of her meal with me, saying, 'I am old, and you are young, it is you who will create the future'". ${ }^{40}$ Based on this handful of examples, the functioning of political prisoners in the criminals' environment appears as an interesting separate issue.

The above-quoted statement by Ms. Olszewska turns our attention to an essential dimension of commonality, supported by political prisoners in Stalinist prisons. The practice of sharing the dispensed food, and the motif of 'kolxoz' - as the inmates (of both sexes) termed their shared prison 'household', supported by parcels received from their families - reappears in multiple accounts. It was an important element of mutual support, since some death-row inmates received abundant parcels from home (or, money to be allocated to the 'canteen fund') whereas some did not, so sharing the food was a means of 'equalling the opportunity' for surviving the prison. ${ }^{41}$

Perhaps the recollections of former political prisoners tend to idealise the past and generalise individual situations; in any case, they take note of the opposite attitude as well. The prisoners admit in their reminiscences that (similarly to what happened in the criminals' cells) there were non-smokers among the inmates, who used the cigarettes received in parcels as precious 'gages' which they sold to their fellow prisoners in exchange for diverse services, or bartered

40 Account of Wanda Olszewska, 2010 (kept in the author's collection).

41 "In the Cracow prison at Montelupich [St.], we set up a 'kolxoz' cooperative, the three of us, from our cause. We shared the contents of our parcels between ourselves fairly”; Tadeusz Bystrzycki (nom de guerre 'Bystry'), 'W więzieniach na Montelupich i Wiśniczu Nowym', in Skałowcy. Wojenne i powojenne wspomnienia żotnierzy Kedywu i Baonu Partyzanckiego „Skała”, ii (Kraków, 1993), 195. 
them. Years afterwards, one of them recollected that a fellow inmate once refused to buy his allotted portion of butter at the canteen for his sick cell-mate. ${ }^{42}$ His behaviour outraged the others. The event was remembered and recollected many years later evidently testifies that moral criteria were applied in prison and sharing goods remained a value, even if not cultivated at every single step.

Similar observations were included a 1952 report on the moods in the Wronki prison, compiled after the inspection of MBP envoys. The report stated that "the 'provisions community' as a form of cementing the prisoners politically has not been found to appear, save for the common sharing of bread which is caused by practical considerations". ${ }^{43}$ The supervisors might have overlooked the shrewdness of the prisoners who knew how to camouflage their 'solidarism' from their 'screws'; this is confirmed by their educational and knowledge-sharing activities. In the Stalinist years, such practices were done under very different conditions than in the pre-war cells for political prisoners: they had to do it covertly, under the risk of statutory penalty; they had to be really careful, and had to be aided by their cell-mates. With no writing aids available, inmates proved really inventive; for instance, a basin was smeared with soap, on which words to be learned were scratched with a piece of fishbone.

Great esteem was always enjoyed among prisoners by those able to tell exciting stories: those could make the monotony of everyday existence more bearable. In the cells for political prisoners, this had an added educational value. Those who could recount interesting stories or recite fragments of prose works or poetry were listened to, as were those with any education and ability to share knowledge. With a considerable proportion of well-educated inmates, and those open for acquiring new information, Stalinist prisons offered extremely abundant possibilities in this respect. Those lecturing in history, literature, philosophy, biology, or agronomy, engineers and even skilled workers, talked to willing listeners. Zdzisław Węglarski, who was arrested in 1948 and sentenced to eight years in prison, recalled:

${ }^{42}$ Account of Bogdan Rusinek, 2010 (kept in the author's collection).

${ }^{43}$ AAN MBP DW, sygn. 1122: Report of the commission composed of Maj. Piątkowski, Deputy Head of Special Department; Capt. Akerman, Deputy Head of Political and Educational Department, to Citz. H. Duljasz, Director of the Department of Prison Management, August 1952, 205. 
"One of the cleverest men I have come across was Zabrzeski, head of the [anticommunist organisation] Freedom and Independence [WiN] in the Land of Tarnów. A doctor by profession, he was also a lawyer and had incomplete higher agricultural education behind him ... Apart from pieces of expert scientific knowledge he shared with us, he entertained us with declaiming long fragments of [Adam Mickiewicz's epic] Pan Tadeusz". 44

Stalinist prisons were filled by people of diverse worldviews; sharing a cell became at times a source of exhilarating impressions in this respect. As Ludwik Ślaski recollected, the cell "was from time to time the scene of altercations, and sometimes baleful arguments incited by [the inmates'] extremely differing views; however, there were discussions too, and interest in the opponent's reasoning arguments". ${ }^{45} \mathrm{He}$ could once listen to fervent discussions in the cell between a Catholic priest and a Jehovah's Witness. The latter 'fought for the soul' of a twenty-year-old cell-mate, together with a communist who also shared the cell - to no avail, though. Ślaski taught the boy mathematics and, to his satisfaction, found him a 'perceptive student'. The aforementioned Zdzisław Węglarski met a communist who had already served time at the same place, in Wronki, before the war: a meeting he found astonishing. The man explained to his cell-mates what is real communism, which was not what the 'People's Poland' pursued, to his mind. He criticised the conditions and the rights offered to political prisoners, compared to those he experienced when imprisoned under the Sanacja - authoritarian regime in Poland in 1930's. Węglarski commented, with a tint of pride, that, in spite of the hardships, Stalinist prisoners carried on the old tradition under the harsher conditions. ${ }^{46}$

The integrity of beliefs demonstrated by those who were put in prison accidentally or at a very young age, could have depended on the people they met behind the bars, who became their carers and mentors. Elżbieta Zawacka, nom de guerre 'Zo', who worked as a pedagogue before the war and served as a Home Army courier during the occupation, got employed as a teacher immediately after

${ }^{44}$ Danuta Suchorowska, Wielka edukacja. Wspomnienia więźniów politycznych PRL 1945-1956 (Warszawa, 1990), 115.

${ }^{45}$ Ludwik Ślaski, Lata wykreślone z życia: proces polityczny $i$ więzienia PRL (Warszawa, 1992).

${ }^{46}$ Suchorowska, Wielka edukacja, 121-2. 
the war ended. Resulting from a single meeting with a courier of the Government of the Republic of Poland in Exile on his secret visit to Poland after the war, she was detained and sentenced to ten years in prison. She initially served time in Grudziądz, then in Fordon, and finally was confined at the juvenile females' facility in Bojanowo. When in Fordon, she applied for work at the prison's school, together with Lidia Krasiborska, whom she knew from the wartime conspiratorial activities, and the governor gave his consent. One of the attending students was Bernadetta Szmidt, an eighteen-year-old political prisoner, who years afterwards thus recollected her prison teachers: "they excelled amongst those confused young people with wisdom as well as with buoyancy and kindness to people, which they tried to transmit to the others". ${ }^{47}$ This was a rather rare example of institutionalised combination of serving the imprisonment and doing a public service, the latter being the ultimate sense of life for both those women.

Characteristic of Stalinist prisons was a certain egalitarianism which manifested itself, among other things, in the fact that politicians with a pre-war record and with strongly established beliefs could be listened to by young people whose main body of experience was, for example, combats in the ranks of a partisan troop, followed by long years in prison. A certain Edward Krywult, young Home Army member, shared a cell for a number of months with Jan Hoppe and Jerzy Braun. They were activists of the Stronnictwo Pracy - the moderate christian democrats group. The communing with these outstanding individuals with interesting personalities and charismas caused that, as he put it years later, "although I had no education then, my education at Wronki made my mind so nimble that I could stand up for an argument struggle with Braun, the great man". ${ }^{48}$ As he admitted, this encounter formed him for the rest of his life. It was with indulgence that Jadwiga Malkiewiczowa, a religious woman with well-established rightist views, recollected the Marxist fascinations of her young female cell-mates, who were brought up into the Catholic tradition: "The infection with the Marxist ideology of the women prisoners serving time in the communist prison was an interesting phenomenon.

${ }^{47}$ Barbara Otwinowska and Teresa Drzal (eds.), Zawołać po imieniu. Księga kobiet - więźniów politycznych 1944-1958 (Warszawa, 1999).

${ }^{48}$ Barbara Otwinowska, 'Więzień - Jerzy Braun', Niepodległość i Pamięć, vii, 1 (1997), 300. 
... It so happened that young and clever girls read Marxist publications and said they never knew those books for nothing like that was ever read in their homes, but this is what is right, and goods must be distributed equally, yes. They found Marxism very akin to Christ's teachings, whereas Christ left the performance of voluntary decision to people. Centuries have proved that voluntary distribution of goods has failed; hence, the principles ought to be put into practice in a coerced way". She endeavoured to dampen their neophyte enthusiasm: "One day, I can remember, a book on the Borgia popes upset the soul of Rysia Z., a very pious girl. She was very outraged, so I tried to calm her down, persuading that this is what the world has always been like: people were always defective ..."49

If not counterbalanced, radical twists in views, particularly among underage political inmates of Wronki, separated as they were from the world and subjected to indoctrination, seem understandable. Bogdan Nowakowski was arrested at a teenage age for his activity with youth conspiracy. When in prison, "it was for the first time in my life that I directly came across Marxist literature. ... I comprehended the nature of exploitation, the importance of the class struggle ... Step by step, I developed a worldview for myself that made me satisfied, and set a goal for me ...", he confessed to Bolesław Bierut in a letter written after his release in 1951, the peaking moment of Polish Stalinism. ${ }^{50}$ His metamorphosis did not meet with acceptance from his cell-mates, though: "I was scorned by the prisoners, and isolated from concordant coexistence with the companions in distress: the only consolation I could find". Interestingly, he complained in his letter about having been doubly rejected since his internal change was not recognised by the prison administration, either: for them, he remained an enemy in disguise. It is difficult to determine how deep this particular result of indoctrination was, or what the actual purpose of the letter might have been. Possibly, the incentive was simply his will to 'rush ahead' and get rid of the stigma of 'anti-State' prisoner which hindered his return to school or work.

For religious prisoners, a means of staying integral and building a sense of community was saying prayers and doing religious practices

49 Jadwiga Malkiewiczowa, Wspomnienia więzienne (Lublin, 1987), 35.

${ }^{50}$ AAN MBP DW, sygn. 76: Letter from Bogdan Nowakowski to Bolesław Bierut (a copy), 1951, 23-4. 
together; such activities were punished by zealous guards: "When I was in the common cell ${ }^{51}$, someone found a hidden missalette on the shelf underneath the table, in the corner behind the victuals box", Jadwiga Malkiewiczowa recollected. The missalette might have been left there by somebody who was about to be set free, or an inmate who was made leave the cell. In any case, it was used in common prayers said out loud, and the female prisoner who was caught reading it out loud was punished with lockup. ${ }^{52}$

Feast days or holidays celebrated furtively are among the most frequently quoted recollections. Their unifying role is usually emphasised; yet, it was not always so, especially when a cell was inhabited by inmates of different confessions. Anna Jakubowska remembered that her Ukrainian cell-mates in Fordon tended to isolate themselves, thereby stressing their religious and ethnic separateness. ${ }^{53}$

The religious differences, so distinctly emphasised, implies the well-informed question about how the Ukrainians and Poles sharing a cell were getting on, separated as they were by the ethnic and political conflict but united in face of the common enemy - the oppressive authorities of communist Poland. The accounts differ from one another at this point; the Poles who reminisce Ukrainians, often emphasise that the discussions around the tough past were an opportunity for them to become acquainted with the arguments of the aliens and to possibly understand them. "My specialty was history, particularly Polish-Ukrainian relations and ethnic minorities' affairs”, Maria Andres, a former Fordon inmate, remembered. "Since there was a Ukrainian woman sharing the cell with us, a teacher by profession and member of the UPA authorities, our discussions on these topics were often quite acute in form. ... we could discuss vehemently but I never quarrelled with Ludka owing to this reason". ${ }^{54}$ The memories imply that such talks caused no deeper grudge or hostility that would have prevented a bearable coexistence in the cell. "Just like us, they have been through severe investigation, high-security gaol, and complete isolation at Inowrocław”, Ruta Czaplińska reminisced. “... Whether we come to

${ }^{51}$ Called ogólniak in colloquial Polish, a common cell was one where prisoners were placed after the investigation was completed.

${ }^{52}$ Malkiewiczowa, Wspomnienia więzienne, 33.

53 Account of Anna Jakubowska, 2011(kept in the author's collection).

54 Suchorowska, Wielka edukacja, 116. 
terms with it or not, they did fight for their homeland's freedom". ${ }^{55} \mathrm{In}$ the opinion of another former prisoner, Wiesława Pajdak-Śmiechowska, Polish women's attitude to their Ukrainian companions depended on where the former came from. Those Poles who had resided in the eastern part of the interwar Polish Republic and knew more on the bloodbaths in Volhynia or Eastern Galicia were much less lenient with the Ukrainian standpoint. ${ }^{56}$

For their part, the Ukrainians also manifested their integrally hostile attitude towards the Poles and the communist authorities. This is traceable in the extant memories of Poles from the Sztum prison, where a considerable group of Ukrainians were kept, as well as in the period's documents. ${ }^{57}$ A 1952 report on the sentiments among the inmates noted: "Prisoner Rachoń, former member of SS Galizien, sentenced under Art. 85 CCPA [Criminal Code of the Polish Army] to fifteen years of imprisonment, clearly said as he talked to the prison authorities: 'I do not regret that I fought against the communist plague, our history is only being written now. The time will come for us to get even with you, and we will butcher the cursed Poles'. He outspokenly talks in Ukrainian only". ${ }^{58}$ The reciprocal enmity could have been fanned by the prison officers. Another Ukrainian, Michat [Myxailo] K., serving his sentence at the Wiśnicz Nowy penitentiary in the South of Poland, recollected a peculiar stigmatisation applied by the prison authorities, rather than conflicts with the Poles: "On the anniversary of Świerczewski's death, [the communist general killed during anti-Ukrainian campaign in 1947] they made things really hot for us ... 'You know what day is today, now go, to the corridor - march, at the double!' They made us do squat-jumps, whilst we barely stood up straight". ${ }^{59}$ Thus, in spite of the coexisting in a community of inmates, the ethnic conflict did not cease to matter: it was recognised, and even reinforced, by the authorities.

${ }^{55}$ Ruta Czaplińska, Z archiwum pamięci. 3563 więzienne dni (Wrocław, 2003), 283.

${ }^{56}$ Account of Wiesława Pajdak-Śmiechowska, 2011 (kept in the author's collection).

${ }^{57}$ Czermański, Więzienie $w$ Sztumie, 266.

58 AAN MBP DW, sygn. 1120: Information on the moods among the inmates, 86.

${ }^{59}$ Account of Michał K., 2011 (kept in the author's collection). [The author, resident of Górowo Iławieckie at the account date, has requested to keep his surname confidential]. 


\section{VI \\ STRUGGLE, OR SURVIVE?}

As has been mentioned, the post-war prisoners had a very limited opportunity to stand up for their rights. They could count on no organisational support from the outside, as the oppositional activities and free press were annihilated in a short time. The clandestine intelligence that functioned in the earliest post-war months endeavoured to collect information on the situation in prisons; news from the outside was from time to time successfully communicated to the prisoners, and secret messages on how the investigation went on smuggled outside the walls. ${ }^{60}$ In Białystok, financial assistance was arranged for political prisoners and their families. Suppositious persons, mostly elderly women, pretended to be the inmates' relatives and in such guise delivered parcels and underwear to them. ${ }^{61}$ These attempts at organised help from the outside came to an end in the first months after the war, but prisoners did not cease to try and organise themselves and did their best to overcome their isolation. Knocking on the wall, using Morse code, was a widespread communication technique, particularly in remand penitentiaries. Stefania Hewelt was twenty when she was confined in the Office of Security [UB] prison at Okopowa St. in Gdańsk, and she had not a faintest idea of Morse code. A prisoner from the cell next to her smuggled a pattern of how to use it, which she incised on the bottom side of the top of a small table fixed on the cell wall and acquired it rather fast. ${ }^{62}$ 'Kites' (written notes) were most often exchanged in criminal prisons, using the agency of inmates doing clearing works or distributing the food. The inmates working as haircutters were tasked with the important function of 'news deliverers', as they systematically visited a number of inmates to give them a haircut or shave them. All these actions had obviously to be done stealthily, and were punished if detected. Sometimes these dealings were done with the knowledge of the guards who were bribed with various 'pledges'. The prison documentation contains case files of investigations against guards who decided to act as such intermediaries for money or different material assets.

${ }^{60}$ Anna Machcewicz, Kazimierz Moczarski. Biografia (Kraków, 2018), 128.

61 Zwolski, Więzienie w Biatymstoku, 308.

${ }^{62}$ Account of Stefania Hewelt, 2010 (kept in the author's collection). 
The places where inmates could enjoy some independence of the external supervisors were infirmaries, hospitals, or prison medical rooms. The accounts offer multiple examples of prisoners working at those facilities and using this relative freedom endeavoured to help their ailing companions receive the necessary medicaments or even go on early release, by forging their health sheets.

Andrzej Ciechanowiecki initiated such inmate conspiracy when confined at Rawicz and, thereafter, at Wronki. This was where Jerzy Woźniak learned from him of the inmate doctors' conspiracy. Initially, he approached him warily, suspecting him of being a provocateur, according to his memories. Ciechanowiecki initiated the idea; being a young boy during the German occupation, he worked for a clandestine social organisation that cared about the Gestapo prisoners. In Rawicz, he ran the hospital chancellery. In coordination with the prison doctors, he set about systematically forging the medical documentation so that the health of the political prisoners looked much more hopeless than it really was, which could have paved for them the way for freedom. ${ }^{63}$ In Wronki, he persuaded more people to join. "At my ward, it was just that some else's x-ray photo was placed in lieu of the original one. The lab assistant was a very decent man too. He was told to get mycobacteria into, and so he did. The risk that our actions might be detected at the tuberculosis ward was not considerable", Jerzy Woźniak recounted. "Theoretically, the chief of staff-at-large could have checked the patients' medical history, but somehow he did not, and filled out the application to free the prisoner instead. We also had a method of destroying evidence of crime: they would not be stored after the prisoner's conditional early release. The used $\mathrm{x}$-ray plates were adapted by the guards: for instance, they would use the celluloid to make visors for children's prams". ${ }^{64}$ The whistle was blown by an orderly, who turned up to be a snitch. At that point, the destruction of the plates proved benign. A dozen, or perhaps more, people owed their freedom to a group of prisoners who had honed their conspiratorial skills during the occupation and used the ready model in the new circumstances. ${ }^{65}$

63 'Przemówienie prof. Władysława Bartoszewskiego na uroczystości jubileuszu Andrzeja Ciechanowieckiego', Kronika Zamkowa, lix/lx, 1/2 (2010).

${ }^{64}$ Account of Jerzy Woźniak, 2009 (kept in the author's collection).

65 'Przemówienie prof. Władysława Bartoszewskiego'; Wiesław Chrzanowski, Pót wieku polityki (Warszawa, 1997), 232. 
Self-organisation of prisoners and all possible forms of 'solidarism', as the interaction and cooperation attitudes demonstrated by the prisoners against the prison administration were referred to in official reports, were ruthlessly eradicated, especially if they appeared as collective fight for the inmates' rights: the fight that was perceived by the prison overseers as a rebellion.

The apparently rational request of a group of women confined in the prison in the Warsaw district of Mokotów who asked for allotting some extra mattresses to their cell which was filled up to the limit, so that the newcomers did not sleep on the floor, was approached along such lines. The prison governor turned up in the cell and listened to Halina Sosnowska, who dared to make a speech in which she referred to political prisoners' rights and mentioning the World Congress of Intellectuals in Defence of Peace which was taking place at that very time in Wrocław (and of which she had read by coincidence, in a paper she surreptitiously got access to). Her address, on behalf of the whole cell, was treated as a revolt; as a punishment, all the women from the cell were put, one by one, into solitary confinement and the parcels, outsiders' visits, yard walks and possibility to contact the doctor were taken away from them. The victimised prisoners could appoint for cancellation of these denials individually to the governor. They turned out to be mutually supportive and unbreakable. ${ }^{66}$

Early in October 1948 a large group of women was transported to the Fordon prison near Bydgoszcz. In Fordon,they were distributed across small cells with six three-storey plank-beds, where thirty-eight women prisoners were placed (two on each of these narrow beds) plus a stinking crapper. They would not go to work for quite a long period of time, had no access to papers or books. Privileges were returned to them with time: visits once in a month through double bars, short letters, parcels once in a month; later on, canteen funds instead. ${ }^{67}$ Women remained under special observation and all their questionable and unorthodox statements, jokes, rebellious gestures or glances were recorded. An opinion on these inmates described them as "... female prisoners coming from underground and spy organisations, landowners' or landlords' ones, or the like. They have formed

${ }^{66}$ Czaplińska, Z archiwum pamięci, 128-30.

${ }^{67}$ AAN MBP DW, sygn. 98: The problem of penitentiary system. A study by Barbara Sadowska, 1953, 9. 
an organised group which mastered the influence on the rest of the inmates and generated a situation that prevented any educative effort. ... Their attitude towards the administration [is] - no fooling around but never read Marxist literature, never hold it in hand, ['] they give it to us to do the canvassing. A war is hanging on a thread, they'll come in to unleash us['], etc. Therefore the daydreaming of them wiping out the communists, inviting [people] to their estates, holding parties, and so on. They have even promised the poorer ones jobs in their factories and demesnes. They have used newspapers for hostile agitation that the USA is preparing a war very soon. Frequenting the political classes [is] all right, just to remain unnoticeable. The administration are boors, so go ridicule the ungrammatical statements when the class is over. [There is the] Acrimonious struggle against cooperating with the administration. Any manifestation of positive attitude toward the People's rule was termed treason; every positive female inmate, a squeaker". ${ }^{68}$ Read years afterwards, this collective opinion of the prison authorities sounds almost grotesque, but shows well the aspects of indoctrination exerted on the guards as regards their attitude to political prisoners, as well as the purely personal dimension related to their sense of their own limitations and lack of prestige. Both threads have, clearly, become the reason for punishing the specified women.

In 1952, a group of sixty-four women prisoners who were regarded the most dangerous were transported to the penitentiary in Inowrocław, where a sort of 'progressive regime' was applied with respect to them. They were placed in one-person cells and completely isolated. According to the report formulated by the administration this oppressive measures taken against them were very effective. "Within six months they all broke down, ceased defying and disparaging, all asked for Marxist literature and newspapers, and for other books ... A few of them disclosed [what] their and their circles' [activities were like] at large. A number of them revealed the organisation that existed at Fordon. It is a fact that some did begin to honestly study Marxism ... all of them, except for one, request for things, rather than claim them. ... Today, all of them are in a condition that they can be talked to, and when moved to common cells they do not do the canvassing like before, and if one of them begins, she is confuted by the others". ${ }^{69}$

68 AAN DW MBP, sygn. 77: Report (handwritten), 76-78.

69 Ibidem, 78. 
The violence used by the officers triggered diverse attitudes among the female inmates - from strengthening their hostility toward the system to breaking human A human being confined in loneliness for years, without a trade to do, no possibility to read, with years ahead of him to live in this way, will be nerve-wracked, and often physically finished and at least grow queer, or, if less psychically resistant, lose his mind. One of the prisoners, Barbara Sadowska in her statement written still in prison but after Stalin's death articulated this ambiguous results of violence openly: "They are broken down physically, psychically, and nervously, but their hostility is kindled; in weak individuals, hostility is merely concealed but it strikes roots more strongly than before ... Isolation inmates are made into heroes suffering for ideals they had not grown to ..."70

This opinion turns our attention to one more aspect of prison existence - namely, the creating of prison idols who turned into characters of legends and myths. Their strength of purpose became the subject of the story but was not necessarily fit for imitation in the prisoner's everyday life. More often than not, prisoners assumed more rational and safe strategies to survive, such as mimicry, avoiding to express their opinion or sentiments aloud. As a general remark, the imprisonment situation fosters hiding one's actual convictions. The strategy of hiding the thoughts and keeping emotions in check was one of the most reliable ways of surviving the prison ordeal for, as one of the victims admitted, "you cannot fret and revolt all the time, can you". ${ }^{71}$

The reports and opinions on prisoners mention the turns in the attitudes of 'anti-State' prisoners who, influenced by the news received from their homes, declared their 'positive' attitude toward the communist regime. One such inmate, "forester by profession, sentenced to fifteen years for his membership with the Home Army", ascertained in a conversation with a Special Section officer at Wronki: "As far as my attitude toward the post-war reality goes, in the first period my attitude was hostile, then I assumed an indifferent position. And when I became realising that the postulates of the July Manifesto [adopted in Chelm on July 22, 1944, by the Polish Committee of National Liberation (PKWN) established by Stalin] were implemented in the

${ }^{70}$ AAN MBP DW, sygn. 98, ditto.

${ }^{71}$ Account of Jadwiga Janiszowska, 2009 (kept in the author's collection). 
daily life, I got over with the [attitude of the communist] camp's enemy". Three other inmates, of working-class background, imprisoned for their resistance, found that their "attitude toward the present regime has been influenced by the letters and visits of their families. The families tell stories of the grand development going on in Poland, of that children attend schools, some even receiving scholarships". This handful of examples may testify to these individuals' revised views and/or a sense of their isolation from the real life. Or, these behaviours might have stood for deliberate mimicry, adopted in order to be classified for a lower-security facility and thereby to survive, till their time in prison ends, in somewhat better conditions.

Hunger-strike was an ultimate and drastic weapon available to prisoners. In the name of fight for their rights or in defence of their confined companions, they deliberately made use of what they were left with: their own body. The aforementioned Barbara Sadowska, formerly a courier with Intelligence I of the Home Army's Headquarters, organised after the war a conspiratorial network code-named 'Liceum', devised to gather information on the situation in Poland; she ran the organisation until detained in spring 1946. In the investigation, she took the blame for building the network entirely on herself and argued that she never operated strictly as an intelligence agent, while her associates were informants of Polish émigré authorities. Sadowska decided to go hunger-striking four times; her target was that all her detained associates be released:

On the fixed date, since none of the revealed was set free, I commenced by fourth hunger-strike, hiding it from the prison guards for almost a week, as I wanted to bring myself to a severe condition before getting artificially nourished. And I succeeded at this point, with the help of several of my cell-mates. After my strike was discovered, I was removed to the prison hospital within the Mokotów [prison] area, and started being artificially fed. ... My condition was quite severe, I cannot recall exactly how much time the hunger-strike took me. But the outcome was successful. Halina Dunin, Zieleniewski, and others were released. It was only later that I learned they were granted indefinite leaves. ${ }^{72}$

The help from the cell-mates is an important detail in this story, for hunger-striking had to be concealed from the guards, which would

72 Halina Waszczuk-Bazylewska, 'Od WW-72 do „Liceum”, Niepodległość i Pamięć, vii, 4/1 (1997), 153-76. 
have been difficult without such interaction. To give another example, Halina Zakrzewska assisted her hunger-striking mate Ewa Piwińska by eating up her portion of food. ${ }^{73}$ Prisoners were faced with extreme choices; helping another man bring his/her own organism to emaciation, so as to make rescuing him/her difficult, may seem an unethical thing to do, but this was the only way to make the protest successful. Tomasz Ochinowski wrote of "moralisation of the life behind the bars", pointing to the fact that prisoners respected the rule of quitting irrelevant daredevilry. ${ }^{74} \mathrm{He}$ also stressed the loneliness in face of the prison challenges as the central dimension of the experience of the repressed individuals. In isolation rooms as well as common cells, during the investigation and talks with the 'experts', everyone had to make extreme decisions on their own. However, the prison community built rules and conduct patterns for themselves, thus responding to the rules of the game superimposed by the adversary - that is, the prison supervisors.

"There is mistrust prevailing among the prisoners, and mutual suspicions of informing the administration, which outright brings about brawls"75, as it was reported to the authorities in the aftermath of an inspection at Wronki. Fear of agents caused that "prisoners fear them more than the prison administration. When writing a request to the Governor, the prisoner is supposed to show it in the cell and all the prisoners correct it. If he applies to Governor for something, he has to exactly tell them in the cell what [the matter] is, and if the cell[-mates] estimate that he had better not report or send ... then such prisoner would not report or send the request". ${ }^{76}$ As is clear then, in the outcome of breaking up the 'solidarism' among the inmates with use of agents, a self-defence model emerged at the Wronki prison.

${ }^{73}$ Müller, If the Walls Could Speak, 156.

74 Tomasz Ochinowski, 'System stalinowski w Polsce z perspektywy doświadczenia więźniów politycznych w latach 1944-1956. Ujęcie antropologiczne i psychologiczne’, in Roman Becker (ed.), Skryte oblicze systemu komunistycznego (Warszawa, 1997), 39-74.

${ }^{75}$ AAN MBP DW, sygn. 1122: Report from Maj. Piątkowski, Deputy Head of Special Department, to the Director of the Department of Prison Management, 14 May 1952, 292.

76 Ibidem, 294. 


\section{VII \\ CONCLUSION}

The group penalisation of a group of female political inmates at the Inowrocław prison was a spectacular act of violence of those in power and, probably, one of the last such strokes. After Stalin's death, with the flight of Józef Światło, the prominent Security Service' officer, to Berlin and his disclosure on Radio Free Europe of the secrets of Communist Poland, the Thaw emerged. A thorough change affected the penitentiary system as well. December 1954 saw the dissolution of the Ministry of Public Security and oversight of penitentiaries was taken over by the Ministry of Internal Affairs; from November 1956 onwards, they reported to the Ministry of Justice. The prosecutorial commissions that appeared in penitentiaries in late 1954 showed more commitment in pointing to poor living conditions of the confined and excessive use of statutory penalties, with the resulting evident improvement in the living conditions and abatement of the strict regime, which extended to political prisoners. The amnesty of 27 April 1956 fairly soon returned freedom to those sentenced for political reasons; yet, apart from the small group of communist prisoners, it did not give them the necessary satisfaction. For decades, they remained stigmatised by their dramatic experience. Some joined in the subsequent years the oppositional activities initiated by the younger generations, but mostly tried to avoid telling stories about what they have been through - an attitude that reminds of the type of mimicry applied by them when under confinement.

The story I have tried to reconstruct heavily draws upon memoirs written down much later and, in most cases, published after Poland regained independence in 1989. In spite of the time distance, the testimony forms a very important counterpoint to the period's tendentious documents, marked as they are with propagandist language. All this makes the search for the truth about the time extremely difficult. All the same, some conclusions might be drawn.

Researchers exploring prison communities, starting with Erving Goffman, highlight the fact that the authority and its subjected prisoners are always in a state of mutual tension. The prison regime restricts and controls the body and the space. In response to this, the prison community creates its own structures, and shapes its members in opposition to the power. 
A political prisoner takes part, in turn, in a broader protest, joining the political current moving on behind the walls and bars. The companions behind the bars become heroes of mass imagination. On the other hand, the cell becomes a scene of exuberant interaction between theory and practice, with the result that this apparently confined place becomes an incubator of politics. Polish communists wrote in the 1920s of a magical power of prison as the space where their community came into being. ${ }^{77}$

There was no magic about Stalinist prisons; those who left those places having long served time there were physically inform and psychically crippled. The authorities managed to smash the structured political resistance; the people confined in the cells remained alone and isolated, and thus assumed diverse strategies to get through the oppression. And even in these extremely tough conditions they could find areas of activity that gave them a margin of freedom and resistance in the struggle for dignity. It was these areas that, eventually, 'unsealed' and modified the entire system.

The attitude of the prisoners, who tried in a variety of ways to build social bonds in the areas of education or medical aid, proved to be extremely important. Such a situation was enabled as prisons were populated by outstanding educated individuals, curious about the world. For those with a smaller potential, contacts with such people could be a source of knowledge and an opportunity for crystallising their own attitudes and beliefs.

The Stalinist system endeavoured to turn prisoners into disciplined executors of the authorities' commands, and a number of prisoners must have stayed obedient. The anchoring in the political, national, or religious tradition certainly inhibited the process, and this social capital appeared to be an important source of resistance to the authorities.

A political prisoner daydreaming of freedom in which s/he would be able to realise at least some of his or her longings and desires - not necessarily revolutionary turns - is a reverse side of political struggle, in a sense. S/he basically remains an empowered human being even in the Stalinist prison, though his/her resistance is reduced to joining or contributing to common prayers, whispered lectures, or silent talks. This activity proves that some part of the

${ }^{77}$ Kenney, Dance in Chains, 263. 
initiative has been intercepted, and heralds the ultimate defeat of the persecutors.

trans. Tristan Korecki

\section{SELECTED BIBLIOGRAPHY}

Cohen Stanley and Taylor Laurie, Psychological Survival. The Experience of Long Term Imprisonment (Suffolk, 1972).

Dominiczak Henryk, Organy bezpieczeństwa PRL, 1944-1990 (Warszawa, 1997).

Dopierała Renata and Waniek Katarzyna, Biografia $i$ wojna. Metoda biograficzna w badaniu procesów spotecznych (Łódź, 2016).

Jarosz Dariusz, Polacy a stalinizm 1948-1956 (Warszawa, 2000).

Kenney Padraic, Dance in Chains. Political Imprisonment in the Modern Word (Oxford, 2018).

Kersten Krystyna and Jerzy Eisler, 'Dyskusja nad historią PRL', Polska 1944/45-1989. Studia i materiaty (Warszawa, 1995).

Muller Anna, If the Walls Could Speak. Inside a Women's Prison in Communist Poland (Oxford, 2018).

Sykes Gresham M., The Society of Captives. A Study of a Maximum Security Prison (Princeton, 1958).

Sztompka Piotr, Kapitat społeczny. Teoria przestrzeni międzyludzkiej (Kraków, 2016). Wolsza Tadeusz, Więzienia stalinowskie w Polsce. System - codzienność - represje (Warszawa, 2013).

Ziemba Zdzisław A., Prawo przeciwko społeczeństwu. Polskie prawo karne w latach 1944-1956 (Warszawa, 1997).

Anna Machcewicz - Stalinist penal system in Poland and in East Central Europe; everyday life in prisons; prisoners of conscience; assistant professor at the Institute of Political Studies, Polish Academy of Sciences;

e-mail: machcewicz@poczta.onet.pl 